http://dx.doi.org/10.4314/ejotmas.v7i1-2.9

\title{
THE UTILIZATION OF LITERARY TECHNIQUES IN FLORA NWAPA'S NEVER AGAIN AND CHIMAMANDA ADICHIE'S HALF OF A YELLOW SUN
}

\author{
*Onyeka IKE
}

\begin{abstract}
This research investigates the utilization of literary techniques in two Nigerian historical fictions: Never Again by Flora Nwapa and Half of a Yellow Sun by Chimamanda Adichie. Nwapa and Adichie are two creative writers belonging to two different generations of Nigerian writers. While the former is of the first, the latter is of the third generation. In their two different novels in focus, it is observed that they deployed diverse literary techniques in variegated fashions to achieve the same goal creating fictional works that deal with the sensitive issues of the Nigerian Civil War. Using new historicism (NH) as its theoretical anchor, this study uses historical-analytic and literary methods to posit that no two creative writers apply literary techniques in an identical manner even when their subject matter is the same. Rather, the deployment of literary tools is usually a function of talent, training, idiosyncrasies, orientation and propensities of a particular author. It is, of course, the patterns of such deployments that create and confer identity and uniqueness to various writers across the globe, such that when a section of the work of a known author is read, his or her name comes to mind. Using New Historicism as a critical searchlight, this paper evaluates compares and contrasts the utilization of literary techniques in the two novels aforementioned. Both writers have utilized literary elements in various ways to foreground and portray the cancerous issues of corruption, ethnicity, nepotism and avarice - the issues that led to the unfortunate and devastating Civil War, and till today continues to limit the progress of Nigeria.
\end{abstract}

Keywords: Literary techniques, NH, Never Again, Nigerian Civil War, Half of a Yellow Sun

\footnotetext{
*Onyeka IKE is of the Department of English and Communication Studies, Faculty of Humanities and Social Sciences, Federal University, Otuoke, Bayelsa State

Email: ikejo@fuotuoke.edu.ng
} 


\section{Introduction}

Individual craftsmanship determines the quality of a literary text; a good literary text often portrays the author's effective manipulation of literary techniques or elements. Such creative ability is mainly a function of talent, training and orientation of the author. Charles Nnolim believes that "technique and structure total up to 'mean' " (159). In terms of the literary ingredients of plot, setting, character and characterization, language and point of view, no two creative works are really identical irrespective of similarities in thematic preoccupation as could be observed in the works of Nwapa and Adichie under study. Although there may be areas of convergence in technique, yet all the elements cannot be the same for even in the so-called identical or homozygotic twins in humans, differences still exist, at least, in their reasoning and ways of doing things. Again, R.L. Stevenson asserts that "the motive and end of any art whatever is to make a pattern" (qtd in Nnolim 131). The making of such a pattern is usually achieved using literary techniques in diverse ways which are often idiosyncratic with various authors; such that the texts of many known writers could be identified when read, even without first mentioning their names. Ngugi wa Thiong'o, for instance, is a creative African writer whose utilization of literary techniques in his texts often places him on the Marxist pedestal as exemplified in his works such as Petals of Blood, Devil on the Cross, I Will Marry When I Want, to mention but a few. It is indeed his manner of utilization of literary techniques that prompts Chinyelu Ojukwu in her landmark research: Perspectives of Change: A Study of Selected Writings of Ngugi wa Thiong'o to refer to him as a writer with "Marxist orientation" (8). Thus, in the words of Stevenson, it could be said that Ngugi, in his artistic works, makes "a pattern" that compels critics to conveniently classify him as a Marxist writer in line with the popular theory formulated and expounded by the German sociologist/philosopher Karl Marx. In most of Ngugi's creative works, the class struggle between the downtrodden/exploited proletariat and the domineering/exploitative bourgeois is often represented and conspicuous too. In this study, it will be seen that Nwapa and Adichie have utilized literary techniques in both similar and divergent forms to create artistic works with similar thematic preoccupation - texts that deal with the issues of the Nigerian Civil War.

\section{Theoretical Scaffolding}

This study is theoretically is based on the New Historicism (NH). NH is a critical theory which evolved in the 1980s mainly through the work of Stephen Greenblatt, and became very influential in the 1990s. The focus of the theory is to comprehend a work of art through its historical 
context and to gain knowledge of cultural and intellectual history through literature which is largely seen as documentation of the history of ideas. Another theorist Michel Foucault based his method on the theory of the limits of collective cultural knowledge as well as on his technique of assessing a large array of documents in order to gain understanding of the episteme of a particular time. The theory is considered to be a more neutral approach to historical events and is sensitive towards diverse cultures. New Historicism is influenced by the Structuralist and post-structuralist models, and operates by reconnecting a work of art with the period in which it was created. Also, it is viewed in line with the cultural and political movements of the time. It assumes that every work of art is a product of the time in history that informed its production. M.H. Abrams and Geoffrey Harpham explain that:

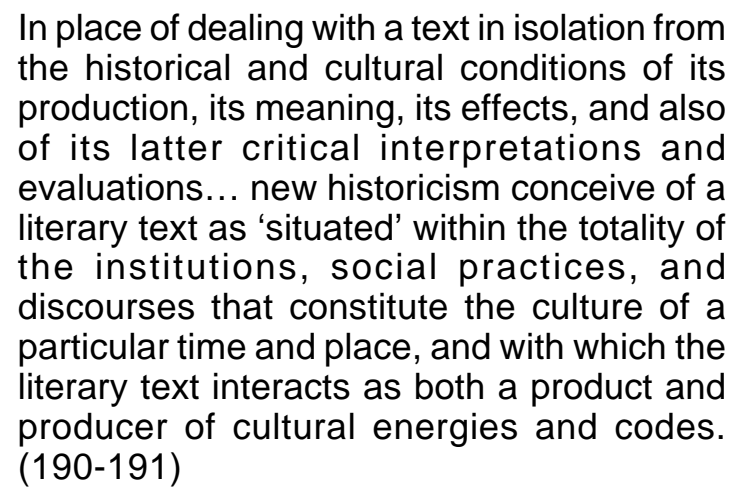

\section{The Plots of Never Again and Half of a Yellow Sun}

Omeh Ngwoke and Gabriel Awuja opine that plot "is the most important element of literature and that its meaning is trailed by controversies stemming from diverse views by scholars" (232). Plot is very significant in literature that some scholars refer to it as 'the soul' of literary endeavours. To E.M. Forster, the concept of plot means a narrative of events, the emphasis falling on causality. It is this emphasis on causality that really differentiates a plot from a story which is a chronological presentation of occurrences. Also, Abrams and Harpham perceive that plot "... is constituted by its events and actions, as these are rendered and ordered towards achieving particular artistic and emotional effects" (233). R.S. Crane views plot as "the temporal synthesis affected by the writer of the element of action, character, and thought that constitute the matter of his invention" (141). While concurring to Crane's perception of plot, Onyemaechi Udumukwu stresses the role played 
by language as one of the vital elements constituting a plot structure. He argues that:

Plot is the element that enables the writer of narrative fiction or drama to achieve or impose a specific order or pattern on language and on life. Plot is pattern on language and life because these are the essential raw materials of literature. Language and life are ubiquitous. But the writer constructs life by using the resources of language in order to achieve a pattern.

No matter the perspective of each scholar on the concept of plot, it obviously involves the arrangement of occurrences or events in a literary work in a pattern of cause and effect. There are different kinds of plot with various distinctive elements which include: thought, language, conflict, character, exposition, complication, climax and denouement. Nwapa's Never Again and Adichie's Half of a Yellow Sun portray two different kinds of plot in utilizing these crucial elements. The plot of Never Again begins with the exposition of why the family of the heroin Kate had to flee from Enugu, Onitsha, Port Harcourt and Elele. A major national conflict - the Nigerian Civil War has broken out and federal troops have attacked the aforementioned cities within the secessionist Biafran enclave. This results to the evacuation of civilians from these cities as they fell one after the other into the hands of the federal troops who are portrayed to possess superior firepower. It is as a result of this consistent evacuations from place to place that the protagonist said, "I was thoroughly tired of life" (5), and earnestly "meant to see the end of the war" (5). The complication that catalyzed the major conflict - the Civil War includes the January 15, 1966 coup; an event of which Kate said, "We had lost our freedom and democracy. We lost them the day that the Army took over. January 15, 1966, was the day when we lost our hard-earned freedom" (36). The negative interpretations given to the January coup by both soldiers and civilians alike precipitates a counter coup which in turn causes bloodshed and pogrom of the Igbo, especially in Northern and Western Nigeria. The inability of the national leaders to properly manage the crisis results to the secession of Biafra and consequently the Civil War.

The climax of Nwapa's narrative comes when the family of the protagonist, Kate, after fleeing from one Biafran town to the other eventually return to Ugwuta their hometown - a place which is supposed to be their final resort. But it is not to be. Not long after they arrived at Ugwuta, there is a rumour of a possible invasion by federal troops. 
This causes so much tension in the community which holds an elaborate town hall meeting to discuss the issue. Obviously, there is fear and suspicion among the people as the word 'saboteur' is brandished and blames are being traded. Eventually, Ugwuta falls for the federal troops, leading to the unspeakable deaths, sufferings, and anguish of men, women, children and even the unborn as the inhabitants evacuate the community. The denouement is portrayed when Ugwuta is recaptured by Biafran soldiers in a matter of days, and the people return to pick up the pieces of their lives. The protagonist emphasizes that as a result of the havocs and devastations wreaked on Ugwuta community by the invading federal forces "the place was desolate" (79). Nwapa's plot in Never Again can be said to be a linear plot in that it is characterized by a single storyline which clearly runs from a beginning to an end. The events of the novel are logically presented as it showcases the elements of exposition at the beginning, conflict at the middle of the story and then a resolution which comes as soon as Ugwuta community is recaptured.

On the other hand, Adichie's plot in Half of a Yellow Sun could be said to be episodic or non-linear. This implies that Half of a Yellow Sun has more than one storyline which are interconnected. The first episode termed Part One is subtitled 'The Early Sixties.' Adichie begins her exposition on how Master's articulate, intelligent and dutiful houseboy Ugwu arrives at the University Campus of Nsukka to live with him. Ugwu is resourceful, obedient, responsible and adventurous, and his relationship with his master Odenigbo and their neighbours is quite cordial as a result of the aforementioned qualities he possesses. The comradeship being shared by some progressive intellectuals of the Nsukka academic community at Odenigbo's house in the evening also forms part of the exposition of this episode. It is also here that the heroine of the novel Olanna is introduced and her relationship with Odenigbo highlighted. The complication of the episode arises mainly from the religious and ethnic prejudice that bedevils the newly independent nation as exemplified in the refusal of Olanna's and Mohamed's parents to allow them to get married because of their ethnic and religious differences. Also, the corrupt tendencies of the First Republic politicians as epitomized in the characters of Chief Okonji the Finance Minister and Chief Ozobia, Olanna's father and a business mogul equally form part of this complication. Then there is the issue of nepotism and ineptitude leveled against the character of Prime Minister Balewa, the arrowhead of the national government.

A minor conflict occurs in this part when Odenigbo's mother Mama clashes with his fiancée, Olanna who she accuses of "controlling" (97) her son and of using "her witchcraft to hold him" (97). It is as a result of this minor conflict that Olanna leaves Odenigbo's house and 
relocates to her own flat in the same university campus. The two lovers reconcile when Mama returns to her home community, Abba after spending several days in her son's house. The return of Mama to Abba and the reconciliation of Olanna and Odenigbo, somehow, signify the denouement of Part One - 'The Early Sixties.' Since this partial denouement does not in any way reflect the major complications of the episode, it only means that greater actions or conflict is being expected. It, however, creates the necessary suspense. Part Two of the novel is subtitled 'The Late Sixties.' It begins with the narrative of the occurrences in Ugwu's family home at Opi as he visits from the house of his master Odenigbo. Although it is tagged Part Two, its beginning shows that it is essentially a continuation of the first part. It is in this part that the conflict which directly results from the complications of the first episode and Part One is clearly demonstrated. Major Nzeogwu announces his coup which implies the termination of Nigeria's First Republic. The coup speech reveals that the reasons for the putsch include: "... to establish a nation free from corruption and internal strife," (123), political profiteering, swindling, tribalism, nepotism and other related vices that were prevalent in the country as brazenly perpetrated by the country's politicians.

Since Major Nzeogwu and other plotters and executors of this coup are mainly of Igbo extraction, the coup is tagged "an Igbo coup" (125). However, without the aforementioned vices being perpetrated by the political class, there would have been no reason for the soldiers to strike. This highlights the cause and effect definition of a plot by E.M. Forster. The coup results to the death of some politicians, including characters of Sardauna, Prime Minister Balewa, and Chief Okonji the Finance Minister. Chief Ozobia, however, is lucky not to have fallen for the bullets of the soldiers. But since he knows that he has a skeleton in his cupboard, he escapes with his wife to London until the dust settles. Barely had the dust raised by Major Nzeogwu's January coup settled than another conflict erupts. A counter coup occurs in the month of July resulting to the death of "many Igbo officers" (138) as well as civilians. Thus, for purportedly orchestrating the January coup, thousands of people of Igbo extraction are killed in the July counter coup by "the Northerners" (138) as a way of paying back. The country is further polarized and largely destabilized even as the butchery of Igbo people continues unabated in Northern and Western Nigeria. The July counter coup and the resultant massacre of the Igbo people coincide with Olanna's second visit to Kano. This affords her the opportunity to witness the gruesome murder of her uncle Mbaezi, Aunty Ifeka as well as other members of the family residing at the Sabon Gari area of Kano. Olanna, however, escapes with the assistance of her ex-boyfriend - Mohammed. Her "dark swoops began 
the day she came back from Kano, the day her legs failed" (156). This debilitating ailment is traceable to the shocks emanating from the gory sight of the dead bodies of her assassinated relatives and of many other people of Igbo extraction, including the plaited head of a teenage girl her mother insisted on putting in a calabash and bringing home after it was severed from the rest of her body. Olanna sits beside this woman in a train on their way back to the East. And as they are about to disembark from the train, the woman opened her calabash to reveal its shocking content.

The shock waves emanating from the incessant news of the massacre of thousands of Igbo people in Maiduguri, Jos, Zaria, Lagos and several other parts of Northern and Western Nigeria destabilize and steal the peace of the entire Eastern Region. Several decapitated and mutilated dead bodies of both the old and the young get to Enugu and Port Harcourt mainly by train. The comradeship that was hitherto shared at Odenigbo's house at Nsukka by the progressive intellectuals disappears alongside with their usual Pan-Africanist debates. Everyone is apprehensive of what the pregnant nation would give birth to. Although initially Ugwu served assorted drinks and peppersoup in Odenigbo's parlour when there was relative peace in the country, he now serves kolanut and then serves nothing at the height of the pogrom. And since there's no meaningful voice of restraint to the incessant killings of Igbo, the rampaging militants add another dimension to their aggression: "The Igbo must go... the infidels must go" (144). The only attempt at restoring order is the Aburi meeting which produces the Aburi Accord duly endorsed by both the characters of Gowon and Ojukwu, the two leaders on the opposing sides. However, the Aburi Accord fails as Gowon refuses to abide by it. It is on account of all these scenarios that Biafra is declared:

... now therefore I do hereby solemnly proclaim that the territory and region known as and called Eastern Nigeria, together with her continental shelf and territorial waters, shall henceforth be an independent sovereign state of the name and title of The Republic of Biafra. (162)

Although the declaration of the State of Biafra is received and celebrated by Olanna, Odenigbo and indeed many Igbo who see it as a sign of liberation from the oppressive Nigerian system, it would mark the beginning of the greatest conflict of the novel - the Nigeria-Biafra War. It is still in Part Two of the novel that several details of the fight are documented. The evacuation of Olanna and her lover Odenigbo from Nsukka to Abba, Umuahia and lastly Orlu with Ugwu and Baby in 
Adichie's Half of a Yellow Sun is quite similar to the evacuation of Kate the protagonist of Nwapa's Never Again and her husband Chudi with their children from Enugu to Onitsha, Port Harcourt, Elele and Ugwuta. Their experiences of hardship occasioned by the war are similar in that in each of these settings they evacuated to, they lacked most of the basic necessities of life which they actually possessed before the war started.

Part Three of Half of a Yellow Sun is subtitled 'The Early Sixties.' This is similar to Part One in both the subtitle and content in that they share the same relaxed mood and atmosphere with which the story started. It begins with Ugwu taking Mr. Richard, the British expatriate writer, to his village, Opi, to witness their annual Ori-Okpa festival. Here again we see laughter and relaxation because there is no threat to peace in any form yet. Obviously, Part Three events had taken place before the events of part two. But because of Adichie's preference for episodic presentation in the novel, this part comes after Part Two. In Part Three, the usual friendly arguments on national and PanAfricanist issues are once again presented as the Nsukka intellectuals chatter exuberantly in Odenigbo's parlour at evenings. It is also in this part that Odenigbo's mother Mama brings Amala to seduce Odenigbo to sleep with her in Olanna's absence. This action is predicated on Mama's longing for a grandchild. However, the action brings a conflict between Odenigbo and Olanna when she returns from her journey. The birth of Baby by Amala in a hospital at Enugu brings complete reconciliation between Olanna and Odenigbo. Olanna likes Baby and decides to take care of her, even though Amala would not touch her, and Mama the arranger of the affair would also reject her simply because she is a girl child; because Mama is actually looking for a male child.

Again, the complication of ethnic prejudice which is a contributory factor to the major conflict of the novel is foregrounded in this part. Olanna's co-traveler in an aircraft on their way from Kano to Lagos reveals that "they have finally removed that Igbo vice chancellor from the university of Lagos" (227). The man is removed from the exalted office not because of any crime or indictment, but simply because he is an Igboman. When the man asked a rhetorical question: "Why should an Igbo man be vice chancellor in Lagos?" and then added, "The problem of Igbo people is that they want to control everything. Everything. ... They own all the shops..." (227), the cause and effect of the vice chancellor's saga crystallize. He had felt free to reveal his prejudice while discussing with Olanna because he thought that she was a Fulani woman: "But you have the face of Fulani people" (227). On realizing that Olanna is not a Fulani but rather an Igbo lady, "the 
man mumbled something... before he turned away and began to look through his briefcase" (227). The occurrences of 'Part Three' show that it is actually a continuation of 'Part One' and that if Adichie has not favoured a non-linear presentation, it would have been a continuation of 'Part One' before 'Part Two'.

'Part Four' which is the final episode is just like 'Part Two.' It is subtitled 'The Late Sixties.' It returns the reader back to the theatre of the Civil War - the major conflict and thrust of the novel. It begins by revealing Olanna's reaction to the series of aerial bombardments that has become a regular occurrence at the Umuahia sector of the war. They had evacuated from Abba to Umuahia before the Biafran capital came under heavy artillery and aerial bombardments by the federal troops who were in a desperate bid to decimate Biafra. "Olanna jumped each time she heard the thunder. She imagined another air raid, bombs rolling out of a plane and exploding in the compound..." (261). This part also chronicles more of the severe hardship the bombarded and blockaded Biafran populace is subjected to. Baby is sick and there is no drug to treat her ailment. There is hardly food for them to eat. This situation compels Olanna to turn to the relief centre to beg for egg yolk - the only kind of food Baby agrees to eat in her sick condition. But it is hardly available. Also, the horrible conditions of people in the refugee camps, especially the one operated by Kainene, Olanna's tough twin sister is revealed. The war is fierce; Biafra lacks weapons and food; Kwashiorkor - the famed Harold Wilson Syndrome takes its toll on the people, especially women and children. The general mood and condition of the people is pathetic - Biafra is losing the war, and by implication their independence. Many are dead; many are wounded; many are sorrowful; many will still die if the condition persists. It is also in this part that Ugwu is conscripted a teenage soldier because Biafra needs more soldiers in the fronts. The war lingers because Ojukwu would not surrender and Gowon would not stop the onslaught. Things get from bad to worse in Biafra on a daily basis. Children's legs turn into spindles as soldiers and civilians resort to every possible means to eat and be alive. It is amidst all these travails that Ojukwu leaves Biafra "in search of peace" and a clear, "unfamiliar and firm" voice of denouement is heard on Radio Biafra:

Throughout history, injured people have had to resort to arms in their self-defense where peaceful negotiation fails. We are no exception... I am convinced that the suffering of our people must be brought to an immediate end. I have, therefore, instructed an orderly disengagement of troops. I urge 
General Gowon, in the name of humanity, to order his troops to pause while an armistice is negotiated. (Half 412)

This announcement in 'Part Four' brings a resolution to the major conflict of the novel. It is important to note that this broadcast, like Major Nzeogwu's coup broadcast in 'Part Two' and Ojukwu's declaration of the Republic of Biafra in the same part, is in reality the historical speeches of the characters concerned. Although Adichie, in the novel does not name the personality or character that makes this broadcast of denouement, the speech is traceable to Major-General Philip Effiong, Odumegwu Ojukwu's second-in-command during the Civil War. Again, the marriage between literature and history is foregrounded, hence, the justification of New Historicism as the applicable theoretical template. Adichie, perhaps, favours episodic presentation in this narrative due to the interval of occurrences of most of the major historical events.

\section{Language and Style in Never Again and Half of a Yellow Sun}

Literature and language are two harmonious companions. M.A.K. Halliday perceives language as a system of arbitrary vocal symbols used in human communication. It is a means of communication between "individuals who share a common code" (Ndimele I). B.A. Okolo and P.A. Ezikeojiaku agree that "in poetry and ritual song, folklore, tales, drama [literature] and ceremony, language has often provided a focus for our deepest religious and aesthetic experiences" (1, emphasis mine). Ruth Finnegan also contends that: the scope of the [literary] artist to improvise or create may vary, but there is almost always some opportunity for composition. It comes out in the exact choice of words and phrase, the stylistic devices...the ordering of episodes or verses, new twists to familiar plot... (Oral Literature in Africa 9, emphasis mine) On the other hand, literature is creative writing of identifiable artistic value. Philip Noss argues that "...good literature has dimension and depth..." (qtd in Chinweizu, Madubuike, and Onwuchekwa 79). Also, Nkem Okoh opines that apart from inculcating values, imparting knowledge, beauty or heightening our awareness of the world around us, "literature enables us to grow both emotionally and intellectually" (Preface 4). These laudable functions are achieved through the creative and imaginative use of language in distinct patterns which is style. Vincent Obobolo affirms that "language and style are inseparable, which implies that every language user uses style in order to express his message in a unique way" (54). In consonance with this perception, Moses Alo notes that "literary style refers to the kind of language that is commonly found in poetry, fiction and drama, and is 
characterized by elegance, beauty in form and language" (3). Daniel Ogum concurs to this view in his Signs-Related Textual Analysis when he states that:

.... the basic thing in literature is the expression of beauty in the imaginative use of language. This aesthetic notion is the basis for associating literature with "belles letters."In literature, words and imitated activities are explored beautifully and imaginatively. Language is used in literature much more figuratively, literarily and connotatively. The basic tool of literature is the word [spoken or written]. (13-15, emphasis mine)

Also, Rowland Barthes contends that "the secret of style is recollection locked in the body of the writer" (qtd in Craig 1). The study of style in a text is known as stylistics. Ikenna Kamalu views stylistics as "a linguistic approach to literature" (Issues 143). Again, Obobolo stresses that stylistics "entails the analysis of distinctive expression in language and the description of its purposes and effects" (39) and that "only the conspicuous (or foregrounded) elements of a text are of stylistic relevance" (40). Charles Ogbulogu agrees to this when he states that: when a particular pattern of speech, language variety of speech [or writing] is associated with a specific social context, stylistics or social meaning is achieved. It is common knowledge that a speaker's [or writer's] choice of words or structures reveals his or her social, regional, geographical or even economic background (22, emphasis mine).

Literary texts, of course, reflect the styles of their authors. Hence, issues relating to disputed authorship are often resolved through the instrumentality of computational stylistics which is the application of statistics to style. At this juncture, however, language and style in the two novels under study shall be foregrounded. In Never Again, Nwapa's diction is simple, clear and easily understandable. This enhances the accessibility of the novel since people at diverse levels of educational development can read and understand it. Although there are obvious literary embellishments, Nwapa's choice of words is mainly from everyday usages and expressions. She also, in most cases, favours simple and brief sentences devoid of convolutions and complications. This is exemplified in the following sentences: "I understood it" (I). "No books taught us thin" (I). "But I had never seen him so angry" (I). "I laughed a mirthless laugh" (I). This type of brief sentences and expressions dominate Nwapa's narrative from the beginning to the 
end. She also uses simple words to convey the imagery of the crisis situation revolving around the Nigerian Civil War.

The following appropriate choice of words and expressions in the novel portray the imagery of the crisis and rancour in Nwapa's society: "fleeing," "tired of life," "death was around the corner," "death was too near for comfort in Biafra," "deadly whine," "war," "shelling," "angry booming," "gun-boat," "exploding," "militia," "rockets," "vandals," "fallen," "separated," "collapsing," frustrations," "threatened," "mercenary," "conquest," "under siege" "amphibious attack," etc. Nwapa uses all these words and many more to portray a society in disorder; a society that has lost its valuable peace. The novel also favours a linear, sequential arrangement of ideas from page to page until one gets to the end of the narrative. Another distinctive feature of Nwapa's Never Again, with respect to language and style, is the use of allusions, especially historical allusions. Nwapa alludes to the massacre of Igbo people in Northern and Western Nigeria when she writes: "They killed us in Lagos, they killed us in Zaria, in Kano, in Jos, in Kafanchan, in Ibadan, in Abeokuta ... My son has been killed by the Hausas. My daughter who lived in Vom has not returned... $(12,30)$. There is also an allusion to Major Chukwuma Nzeogwu's 15 th January, 1966 coup when she writes: "January 15 1966, was the day when we lost our hard-earned freedom" (36). Again, in narrating the invasion of Ugwuta by federal troops and its recapture by Biafran forces in a matter of days, Nwapa also alludes to some actual historical experiences of Ugwuta community in the present day Imo State during the Civil War.

Adichie's discourse in Half of a Yellow Sun portrays her as an articulate user of language. Although there is a balance or seemingly proportionate use of simple, compound and complex sentences, her diction, like Nwapa's is simple and also comprehensible. However, one could still observe that Adichie's choice of words and manner of articulation is slightly elevated in comparison to Nwapa's. Again while Nwapa's arrangement of ideas in her narrative runs continuously on a sad, disappointing and tragic note, Adichie's narrative is an admixture of stories of peace, love and war coherently fused together. This is why her diction could convey divergent imageries beyond crisis and disorder. Such words and expressions include: "smelt something sweet," "hedges trimmed so flat," "well dressed men," "a good man," "bungalows... painted the colour of the sky," "the lawn glistened," "good fortune," "embroidered with gold," "cocktail party at Ikoyi Hotel," I love you," "I really love you," "soft chest," "fish pepper soup," "burgundy carpeting," "sturdy room," "beautiful daughter," "Lagos Life," "sex bait," "fell in love," etc. These words and expressions are in sharp contrast to other ones in the same novel like "suspended," "dissolved," 
"enemies," "divided," "internal strife," "corrupted our society," "oppression," "killed," "evil man," "tumultuous," "coup," "pogrom," "massacre," "blood-smeared," "legs failed," etc. While the latter group of words and expressions are similar to what can be found in Nwapa's Never Again, the former are entirely different. Again, like Nwapa, Adichie employs some of the later words and expressions to make certain historical allusions to some of the ugly events of that historical era including the pogrom of the Igbo people in some parts of the country after the July counter coup. And when she takes the reader fully to the theatre of war in 'Part Two' and 'Part Four,' her choice of words fully reflect those bloody moments.

Adichie also employs the technique of intertextuality to pass her messages across in the novel and reflect meanings. This term is often linked with the technique of allusion. It shows that fictional works do not in any way exist in a social and historical vacuum. Rather, they reflect other texts. Intertextuality as a word was initially formed by poststructuralist Julia Kristeva in the year 1966. The concept of intertextuality is a clear demonstration that the meaning of a text does not reside in the text alone but is synthesized by the reader in connection to other texts in the process of reading. Adichie's allusion to and reproduction of a part of Nzeogwu's coup broadcast of $15^{\text {th }}$ January, 1966, Ojukwu's declaration of the Republic of Biafra as well as Effiong's broadcast of the surrendering of Biafra as earlier cited are clear exemplifications of intertextuality in Half of a Yellow Sun. There is also the use of conjunctions in the novel to achieve lexical cohesion as exemplified: "They had been walking for a while now, since they got off the lorry at the motor park, and the afternoon sun burned the back of his neck. But he did not mind" (I). The conjunctive elements and, but are used to achieve cohesion in the discourse. Also, in various parts and pages of the novel, Adichie achieves cohesion using reference as a veritable device. This is demonstrated thus:

In the following weeks, the weeks when he examined every corner of the bungalow, when he discovered that a beehive was lodged..., he was just as careful in learning the rhythms of Master's life. Every morning he picked up the Daily Times ... He had the Opel washed before Master finished breakfast... (13)

Here, the use of personal pronoun he as it refers to Master's servant Ugwu is used to achieve reference cohesion. Adichie also profoundly uses reiteration in Half of a Yellow Sun to achieve lexical cohesion as shown: he would never be able to describe to his sister 
Anulika how the bungalows here were painted the colour of the sky and sat side by side like polite, well-dressed men, how the hedges separating them were trimmed so flat on top that they looked like tables wrapped with leaves (I). In addition, Adichie sprinkles a myriad of Igbo words and expressions in her narrative to create a kind of local flavour. This is obviously a distinct style she chooses to adopt, even in her other novels like Purple Hibiscus and Americanah. Being conscious of the fact that she is writing for a global audience she often places such words or expressions in context, so that non-Igbo readers can understand them without any difficulties. In Half of a Yellow Sun, such include: Oga gi kwanu?, Ikpotago ya?, Nee anya, I nugo?, Kedu afa gi?, osiso-osiso, Ngwa, dibia, kedu? And so on.

Indeed, language and style are very crucial elements in any literary text. Roger Fowler maintains that "style resides in the manipulation of variables in the structure of language or in the selection of optional or latent features" (8). The necessity of style in a literary text, Ngara believes, is "to judge the success of the writer's wrapping technique in relation to the value of the parcel" (27). This is actually what accounts for the peculiarity of a text. Nwapa and Adichie are undoubtedly distinguished Nigerian writers whose language and style of writing appeal to many readers across the globe.

\section{Setting}

Every fictional or dramatic work has a place, and a time that make up the environment of its occurrences. Abrams and Harpham state that "the overall setting of a narrative or dramatic work is the general locale, historical time, and social circumstances in which its action occurs..." (294). Asiegbu and Koroye agree that the "setting is the condition in which a story takes place" (270), and that "the importance of setting to the understanding and interpretation of a creative work, therefore, cannot be overemphasized" (271). Udumukwu also defines setting as "the conscious representation in fiction and drama of the place and time that constitute the environment of the action" (56). In stressing the importance of setting in fiction and drama he further states: for the literary communication to be effective as a resourceful link with the listener and at the same time engage the analytical eye of the student, drama and fiction require a locale or geographical setting. It is within this locale that the communication can be understood and the listener can gain a firm orientation (56).

The overall setting of Never Again is postcolonial Nigeria between 1967 and 1970; and the settings for the particular scenes where most of the actions in the fiction occur include Port Harcourt and Ugwuta which are within the secessionist Biafran enclave. Adichie's Half of a 
Yellow Sun is also set in postcolonial Nigeria between 1960 when the country gained her independence from Great Britain to 1970 when the Civil War ended. Settings for particular scenes where significant actions occur include Lagos, Kano, Nsukka, Abba, Enugu, Umuahia, Port Harcourt and Orlu. The difference between the overall setting of Never Again and Half of a Yellow Sun is that the later captures Nigeria's immediate postcolonial experiences between 1960 and 1966/67 when certain major crisis that rocked the nation erupted while the former focuses mainly on the occurrences between 1967 when the war started until 1970 when it ended. Again, settings for particular scenes of actions are also wider as earlier stated. This implies that in terms of general "locale," "historical time" and "social circumstances," Half of a Yellow Sun is much wider in coverage than Never Again although both fictions are set in postcolonial Nigeria.

\section{Character and Characterization in Never Again and Half of a Yellow Sun}

In A Glossary of Literary Terms, Abrams and Harpham state that:

Characters are the persons represented in a dramatic or narrative work, who are interpreted by the reader as possessing particular moral, intellectual, and emotional qualities by inferences from what the persons say and their distinctive ways of saying it the dialogue - and from what they do - the action. (33)

Characterization, they say, means "establishing the distinctive characters of the persons in a narrative: showing and telling" (34). On his part, Udumukwu explains that "characters are the imaginary actors in a dramatic text or fiction whose moral and disposition as revealed in the course of the action are patterned after real life" (Character 236). Emphasizing the role of characters in a literary work, Udumukwu points out that: "Characters bring the story to life and through them we can see literature as language that walks and talks before us" (236). Characters are fictional actors in a creative work upon which the writer confers attributes and qualities while characterization could be described as the imaginative delineation of characters in a creative work. In the articulation of Never Again and Half of a Yellow Sun, Nwapa and Adichie have employed different types of characters to illuminate their novels. It is also through the delineation of these characters that vital messages are passed across to the reader.

The major characters of Nwapa's Never Again include Kate, Chudi her husband, Kal their family friend and Madam Agafa the woman 
politician whose immense contribution at the Ugwuta Community Town Hall Meeting is quite outstanding. The main actions of the novel revolve around these principal characters. Kate could be described as a flat and predictable character. She is outspoken, resourceful, courageous and resilient even in the face of a serious crisis and severe pressure. In the face of death, Kwashiorkor and all manners of problems orchestrated by the Civil War and constant evacuation of her family from place to place, Kate said, "I wanted to live so that I could tell my friends on the other side what it meant to be at war - a civil war at that ..." (I). It is actually this statement that motivates all her actions throughout the novel. She wants to survive the war; to live and be able to tell the story afterwards. Kate as a character in Never Again is like Kainene in Half of a Yellow Sun in that the two Biafran women are bold, resourceful, and outstanding. Above all, they possess unquenchable survival instincts. They are portrayed to be capable women who know what to do in the face of any challenge.

Rather than succumb or surrender to despair or difficult situations, the two women are always sources of inspiration and encouragement to those around them, including men. At the heat and height of the Civil War, Kainene runs a commendable refugee camp in her bid to contribute to the "win-the-war" effort. She handles various supply contracts during the war and becomes the breadwinner to those around her including her fiance Richard Churchhill, Harison, Ikejide, and even Olanna and her family members - Odenigbo, Ugwu and Baby who later came to be with them in their residence at Orlu towards the end of the war. Kainene believes so much in the State of Biafra and wants it to survive and blossom against all odds. In fact, her laudable "winthe-war" efforts are motivated by her desire to see that Biafra survives. When there is extreme hardship and scarcity of food to run her refugee camps, she takes the risk and courageously dashes across enemy lines to look for food at all costs. Unfortunately, she mysteriously disappears in the process. Kainene is a flat character in that her sardonic, courageous and enterprising nature remains significantly unchanged and predictable throughout the novel.

Like Kate and Kainene, Madam Agafa the woman politician in Never Again is also bold and resourceful. When the invasion of Ugwuta Community by federal troops is rumoured she stands even amidst the men folk in a town hall meeting to encourage the fainthearted and to declare her unflinching support for Biafra. Her speech: my fellow Ugwuta people ... I am for Biafra. I am for Ojukwu .... You all know that I lost all my property in Warri... That is beside the point. I don't mind all that. That is my sacrifice for Biafra; for the cause of Biafra. There is no sacrifice too great for Biafra. I am prepared to die for Biafra. Why are we running? We are running from the vandals. Who are the 
vandals? They are nobody. We must continue fighting against them until we vanquish them. God is alive and God knows that our cause is just... (11-12). Although Madam Agafa is bold and courageous as demonstrated in her speech, she cannot be regarded as a flat character. She is rather a round and complex character. Madam Agafa is multidimensional, emotional, and really surprises the reader when, in spite of her bold contributions at the town hall meeting, she surrenders to despair at the eventual fall of Ugwuta to the federal forces. She succumbs and weeps, up to the point that several other women gather around her to console and encourage her as she laments that:

Ugwuta Ameshi, Ugwuta Ameshi e e, are you there? Is Uhamiri there? Do you see? Sabo, you have done your worst. I am a dead woman. I am a dead and wretched woman. My God, my people, have you seen my nakedness? ... what kind of thing is this? (58)

At this point, the narrator states that Madam Agafa is "surrounded by women, the prayer group" (59). It is also reported that "she was sweating profusely, and some women were fanning her" (59). The reaction of Kate's mother-in-law to this situation is more revealing of the round and complex character of Madam Agafa: What are you all doing here weeping? You have not started to weep. You will weep for a long time to come. Agafa get up, get up. Why do you stay here allowing these women to weep on you? Are you insane? Have you gone out of your mind? Why are you behaving like a child? Get up quickly I say. We are alive. We shall pick up again (59). Here, it is quite surprising to see the same bold lady who stood firm at the town hall meeting, like the Rock of Gibraltar, to encourage even the men folk melting to this point when the chips were down. This kind of behaviour is typical of round characters - a clear demonstration of the true human nature. As a round character, Madam Agafa is like Adichie's heroine Olanna in Half of a Yellow Sun. She is an epitome of beauty and attractiveness. Olanna is in all ramifications an admirable character. Although she is portrayed in most parts of the novel as a dependent lady; one who often looks up to others for approval and affection, Olanna could be bold and resolute. Thus despite her initial portrayals, Olanna surprises the reader when she courageously confronts her father Chief Ozobia for his infidelity to her mother, and latter challenged her mother for maltreating Maxwell their family driver in a way she does not like; because he stole a few cups of rice from their kitchen. Her reaction at this juncture obviously portrays her as a resolute and courageous personality: 
The driver's pleading hands faced Olanna. "Please beg madam."

Olanna looked away from the man's lined face and yellowed eyes; he was older than she had first thought, certainly above sixty. "Get up," she said. He looked uncertain, glancing at her mother.

"I said get up!" Olanna had not intended to raise her voice, but it had come out sharp. The man stood up awkwardly, eyes downcast.

"Mum, if you're going to sack him, then sack him and have him go right away," Olanna said. (220)

Later in her discussion with Odenigbo, she reveals the motivation for her action: "My father and his politician friends steal money with their contracts, but nobody makes them kneel down to beg for forgiveness" (221). In Never Again, Kate's husband Chudi is a flat character. From the outset of the narrative, he is portrayed as an easily irritated person; one who readily reacts to situations when provoked. When his wife Kate tells him of the impending fall of Port Harcourt into the hands of federal forces, his first reaction to a mere comment from his wife is a revelation of the content of his character: I had told Chudi that Port Harcourt was in great danger, and would fall at any time. This was about two months before it actually fell. He was so upset that he threatened to hand me over to the Civil Defenders or the militia. We had been married for fifteen years and had five children (5). It is in this state of anger that he further reacts: "If you think, woman, that we are going to leave Port Harcourt for the vandals you are making a great mistake, he roared" (5). At the town hall meeting and at the eventual fall of Ugwuta their community, Chudi maintains the same irritable and angry disposition. The narrator, again, captures this when she states: "They paraded, molesting women who had already started fleeing ... My mother-in-law and the children all burst into tears. My husband ignored them" (51). Throughout the novel, Chudi's behaviour is dominated by "panic" (51) and anger such that when once his name comes up in any scenario, one expects the same reaction.

On the other hand, $\mathrm{Kal}$ is a round character; a man full of surprises. The first time one meets $\mathrm{Kal}$ in the narrative, he is described as a "good friend" (6) of Kate's family and a firm believer in the Biafran cause: Kal had been very strange of late. He was so pro-Biafran that I had begun to be scared of him. But he was not the type to take me to the Civil Defenders. He still had good sense in him. He sat down and I gave him something to drink. It was Vodka (6). Although Kal's mission in Kate's house in Port Harcourt at this moment is to reassure them that the city would not fall for the federal forces, and that Biafran forces are fully in control, he is one of those who disappears from the city early as soon as the shelling intensify. The narrator also portrays $\mathrm{Kal}$ as a philanderer who is running after another family friend Bee 
although he is married: "Kal was running after Bee then though he was married" (7). It is in his philandering attitude that Nwapa's Kal can first be compared with Adichie's Odenigbo, another round character. Although Odenigbo is seriously in love with Olanna as a fiancée and has been living with her in his Nsukka residence, yet in a short moment of her absence, he could not resist the temptation of sleeping with Amala who later gave birth to a baby girl. When they evacuated to Umuahia, Odenigbo will, again be involved in another affair and would warn Ugwu not to let Olanna know about it.

Again, at the outset of Half of a Yellow Sun, Odenigbo is portrayed as a firm, focused and decisive character, yet during the war, when they are at Umuahia, he could get drunk to the point of returning home to vomit alcohol with which he messed up his entire living room. In displaying this shade of behaviour, Odenigbo surprises the reader as a round character in the novel. It is also in this manner that Kal in Never Again, once more surprises the reader when he, again, disappears from Ugwuta without the knowledge of Chudi and Kate, his friends. Although Kal, as he did in the Port Harcourt scenario, is among the seemingly courageous individuals advocating for the residents of Ugwuta to stay put and not evacuate, he quickly disappears from the community as soon as he is certain of the invasion of the federal forces. This, of course, is another surprise to the reader. He would reappear towards the end of the narrative, to Kate and his family members in their refugee camp, as a major in the Biafran Army. The narrator captures the surprises in the character of Kal this way: The following morning, Kal came. He came in army uniform. He was a major. Kal had enlisted in the army. He came in a commandeered car. $\mathrm{Kal}$ had his own car which he had hidden somewhere and used somebody else's... He was full of himself as usual. How come that he had enlisted so soon after the fall of Ugwuta? When was he trained? His shoulders showed that he was a major. Wonders would never cease, $\mathrm{Kal}$, a major (76).

Furthermore, Richard the British writer and Kainene's fiancé in Adichie's Half of a Yellow Sun could be described as a round character. Like Olanna, he is often portrayed as a dependent person. But he also demonstrates that he could be courageous and resolute. On arrival in Nigeria, he develops an intimate relationship with Susan, a fellow expatriate who readily welcomes him into her embrace and to her well-furnished house. The relationship is, however, dominated by Susan who is portrayed as an outspoken, outgoing person. But when Richard gets bored of Susan's bossy attitude and, indeed, of the relationship, he is bold enough to tell Susan and to quit. This is in preference to Kainene, an African lady. Again, Richard's adventurous 
journalistic endeavours in favour of Biafra during the war also portray him as a decisive character.

\section{Narrative Points of View in Never Again and Half of a Yellow Sun}

Abrams and Harpham state that point of view is "the way a story gets told - the mode (or models) established by an author by means of which the reader is presented with the characters, dialogue, actions, setting, and events which constitute the narrative in a work of fiction" (272). Udumukwu posits that "point of view amounts to all the various ways in which we can understand the relationship between the narrator and the audience...that is the perspective from which the story is told" (A Guide, 72). Kamalu asserts that point of view "... is so central to the construction, presentation, and study of narratives that without it no story gets told because a story must be told or presented from a particular point of view" (293). Point of view is the narrative position or view adopted by a writer to tell his or her story. The major classifications or typologies include first-person point of view, second-person, and third-person point of view otherwise known as omniscient point of view. A close examination of Nwapa's Never Again reveals her adoption of first-person point of view in the narrative. In the first-person point of view, the narrator is a participant in the story he or she is telling. This is to say that the narrator may be a major or a minor character in the story, and the use of the first-person pronoun "I" is significant. R.S. Gwynn believes that: In general, first-person stories seem more immediate than third-person stories, but they are limited by the simple fact that the narrator must be present at all times and must also have some knowledge of what is going on (15). Kamalu states that "the predominant use of the pronoun I reveals that the narrator is an active participant in the story he is presenting and the story also revolves around him" (297). Nwapa's story in Never Again revolves around Kate, the heroine, narrator and principal character of the narrative. This is amply demonstrated in the opening paragraph of the story: After fleeing from Enugu, Onitsha, Port Harcourt and Elele, I was thoroughly tired of life. And for us who had known no danger of this kind before it was hell on earth. I meant to live... I meant to see the end of the war. I wanted to live so that ... I wanted to tell them that... I understood it. I heard the deadly whine of shells (5).

On the other hand, Adichie's narrative in Half of a Yellow Sun favours the third-person or omniscient point of view. Kamalu observes that "an omniscient point of view emerged from the notion that the narrator is all-knowing and is by no means restricted in time and space - such a narrator has unrestricting information to what a character 
sees, hears, feels and thinks" (298). Porter H. Abbot employs the lexeme "distance" (74) to reflect the level of involvement of the narrator in the story being told. This point of view uses the third-person pronouns "they" and "he" as opposed to the "l" and "us" usually employed in the first-person point of view. A close study of Half of a Yellow Sun shows that Adichie uses third-person point of view as exemplified:

\begin{abstract}
Ugwu did not believe that anybody, not even this master he was going to live with, ate meat every day. He did not disagree with his aunty, though, because he was too choked with expectation, too busy imagining his new life away from the village. They had been walking for a while now, since they got off the lorry at the motor park, and the afternoon sun burned the back of his neck. (3)
\end{abstract}

The third-person point of view obviously gives the narrator the advantage of knowing all occurrences and behaviour of characters in a story, including their thoughts, and consequently articulating as much as he or she desires or is capable of capturing.

\title{
Conclusion
}

Never Again and Half of a Yellow Sun are two historical fictions which clearly demonstrate that writers deploy literary techniques in diverse ways to foreground meaning even with a subject matter. While Nwapa's plot in the former can be said to be linear since it portrays a single storyline which runs from a beginning to an end, with the events of the novel logically presented as it showcases the elements of exposition at the beginning, conflict at the middle of the story and then a denouement which comes as soon as Ugwuta Community is recaptured, Adichie imposes a non-linear plot in Half of a Yellow Sun which possesses more than one storyline that are, however, interconnected to constitute a single novel. In terms of language and style, Nwapa can be said to be simple because her choice of words is mainly from everyday usages, expressions and sentences devoid of convolutions. Adichie's diction and manner of articulation is elevated and convoluted in comparison to Nwapa's. The disparity between the overall setting of Never Again and Half of a Yellow Sun is that while the former focuses mainly on the occurrences between 1967 when the war started and 1970 when it ended, the latter, in addition, captures the nation's immediate postcolonial experiences between 1960 and 1966/67 when certain major national crises which serve as precursors to the war erupt. Finally, with regards to point of view, Nwapa's narrative is 
presented in the first-person point of view while Adichie favours thirdperson or omniscient point of view. Both writers deployed flat and round characters to convey vital messages to the reader and warnings to a nation that hardly learns from history.

\section{Works Cited}

Abrams, M.H., and Geoffrey Harpham. A Glossary of Literary Terms. $8^{\text {th }}$ ed. Boston: Thomson Wadsworth, 2005. Print.

Abbott, Porter $\mathrm{H}$. The Cambridge Introduction to Narrative. $2^{\text {nd }}$ ed. Cambridge: Cambridge University Press, 2008. Print.

Adichie, Chimamanda N. Half of a Yellow Sun. Lagos: Farafina, 2006. Print.

Alo, Moses A. Style in Language and Communication. Port Harcourt: Aeddy Link Publishers, 1998. Print.

Aristotle. Poetics. Trans. Michael Heath. London: Penguin Books, 1996. Print.

Asiegbu, Perp' St. Remy, and Seiyifa Koroye. "Setting." Introduction to Literature. Eds. Onyemaechi Udumukwu, Ikenna Kamalu, and Oyeh Otu. Port Harcourt: Obisco Nigeria Enterprises, 2014. 270-292. Print.

Craig, Hugh. "Style, Statistics, and New Model of Authorship," 2009. Web. Retrieved on $8^{\text {th }}$ August, 2016. From <URL: http:// porl.oclc.org/em/s/15-1/Craistyl. htm>

Crane, R.S. "The Concept of Plot." The Theory of the Novel. Ed. Philip Stevick. New York: The Free Press, 1967. 141-151. Print.

Chinweizu, Ihechukwu Madubuike and Onwuchekwa Jemie. Towards the Decolonization of African Literature. Enugu: Fourth Dimension Publishers, 1980. Print.

Finnegan, Ruth. Oral Literature in Africa. Nairobi: Oxford University Press, 1970. Print.

Francis, Taylor. "Flora Nwapa, Never Again." Retrieved 12 ${ }^{\text {th }}$ May, 2016 from http://www.tandfonline.com. Web.

Forster, E.M. Aspects of the Novel. London: Penguin Publishers, 1976. Print.

Foucault, Michel. "The Order of Discourse." Untying the Text: A PostStructuralist Reader. Ed. Robert Young. London: Routledge, 1981. 34-74. Print.

Fowler, Roger. "Linguistic Theory and the Study of Literature." Essay on Style and Language: Linguistics and Critical Approaches to Literary Style. Ed. Roger Fowler. London: Routledge and Kegan Paul, 1966. Print.

Gwynn, R.S. Fiction: A Harper Collins Pocket Anthology. New York: Harper Collins College Publishers, 1993. Print. 
Hamilton, Paul. Historicism: the New Critical Idiom. $2^{\text {nd }}$ ed. London: Routledge, 2003. Print.

Halliday, M.A.K., Mckintosh, A. and Strevens, P. The Linguistic Sciences and Language Teaching. London: Longman, 1964. Print.

Kamalu, Ikenna. "Point of View." Introduction to Literature. Eds. Onyemaechi Udumukwu, Ikenna Kamalu, Oyeh Otu. Port Harcourt: Obisco Nigeria Enterprises, 2014. 270 - 292. Print.

_ _ _. "Stylistics." Issues in the Study of Language and Literature: Theory and Practice. Eds. Ikenna Kamalu, and Issac Tamunobelema. Ibadan: Kraft Books Limited, 2015.143-168. Print.

Ngwoke, Omeh O., and Gabriel Awujah. "Plot." Introduction to Literature. Eds. Onyemaechi Udumukwu, Ikenna Kamalu, and Oyeh Otu. Port Harcourt: Obisco Nigeria Enterprises, 2014. 223 - 233. Print.

Ndimele, Ozo-Mekuri. Morphology and Syntax. Port Harcourt: Aeddy Link Publishers, 1998. Print.

Ngara, E. Stylistic Criticism and the African Novel. London: Heineman Educational Books, 1982. Print.

Nwapa, Flora. Never Again. Enugu: Nwamife Press, 1975. Print.

Ogum, Daniel N. Stylistics: Signs-Related Textual Analysis. Port Harcourt: Abe Publishers, 2010. Print.

Oboboblo, Vincent. "Language and Style." Introduction to Literature. Eds. Onyemaechi Udumukwu, Ikenna Kamalu, and Oyeh Otu. Port Harcourt: Obisco Nigeria Enterprises, 2014. 39-54. Print.

Ogbulogo, Charles. Concepts in Semantics. Lagos: Sam Iroanusi Publications, 2005. Print.

Ojukwu, Chinyelu. Perspectives of Change:A Study of Selected Writings of Ngugi wa Thiong'o. Port Harcourt: University of Port Harcourt Press, 2014. Print.

Okolo, B.A., and P.A. Ezikeojiaku. Introduction to Language and Linguistics. Benin: Mindex Publishing, 1999. Print.

Oko, Nkem. Preface to Oral Literature. 2nd ed. Port Harcourt: Pert Publishers, 2010. Print.

Otu, Oyeh O. "Race and Identity Politics in Selected Plays of August Wilson." Diss. University of Port Harcourt, 2015. Print.

Perry, Alison. "Never Again by Flora Nwapa." 13 ${ }^{\text {th }}$ May, 2016 http:// africaworldpressbooks.com. Web.

Udumukwu, Onyemaechi. Literary Theory and Criticism. Port Harcourt: Charles Martins Higher Education and Consulting Company, 2015. Print.

A Guide to Narrative Fiction and Drama. Port Harcourt: Emhai Printing and Publishing Company, 1997. Print. 
."Character and Characterization." Introduction to Literature. Eds. Onyemaechi Udumukwu, Ikenna Kamalu, and Oyeh Otu. Port Harcourt: Obisco Nigeria Enterprises, 2014. 234 - 252. Print. "War's Other Voices: Adichie's Half of a Yellow Sun and the Biafran War." Signature of Women: The Dialectics of Action in African Women's Writing. Owerri: Onii Publishing House, 2007. 107-129. Print.

"Ideology and Point of View in the Nigerian Civil War Fiction." Social Responsibility in the Nigerian Novel. Port Harcourt: Sherbrooke Associates, 1998. Print.

wa Thiong'O, Ngugi,. Devil on the Cross. London: Heinemann, 1982. Print.

. Petals of Blood. London: Heinemann, 1977. Print.

- - . I Will Marry When I Want. London: Heinemann, 1982. Print. 